\title{
Implementation of Labor Overtime Protection of PT Hwaseung Indonesia
}

\author{
Metry Widya Pangestika*) and Arpangi**) \\ ${ }^{*}$ )Master of Laws Sultan Agung Islamic University (UNISSULA) E-mail \\ metry.widya.mw@gmail.com \\ ${ }^{* *}$ ) Faculty of Law Universitas Islam Sultan Agung
}

\begin{abstract}
.
This study is based on the legal problems of the workforce who work overtime hours at PT Hwaseung Indonesia. This research uses empirical juridical law research methods aimed at analyzing the implementation of legal protection of overtime work of PT Hwaseung Indonesia. Legal protection at PT HWI has not been fully implemented in accordance with Article 78 letter $b$ of the Employment Law No.13 of 2003 that is, overtime work can be done a maximum of 3 hours in 1 day, and 14 hours in 1 week. Kepmen. No. 233 / MEN / 2003 allows its employees to work beyond the provisions of Law No. 13 In 2003, the original work was done according to the type and nature must be continuous. Although there are violations of overtime hours, the implementation of legal protection against workers beyond overtime has been done by PT. HWI, that is, by requesting the consent of workers before committing overtime and providing overtime wages. It is hoped that through this research will be found new ideas of thought that are useful for the Indonesian Ministry of Transport. Where the results of the research can be used as an indicator in conducting labor surveillance, in order to find ideas on how labor regulations play a greater role for the human rights of workers.

Key word: Implementation, Overtime Time, Law No. 13 of 2003
\end{abstract}

\section{Introduction}

Indonesia as one of the countries that currently enhance development in various sectors with the aim of prospering Indonesians Indonesian people. The workforce also supports this development without knowing what it is tired of, trying to raise the company's image, as well as to meet its needs. Referring to this, the government should immediately try to protect and pay attention to its workforce.

Increased recognition of human rights (HAM) is a form of protection of workers other than physical, technical and socio-economic protection through the rules that exist in the workplace. Law No. 13 of 2003 on Labor obliges all employers to implement the provisions of hours or work time, however, it does not apply to the business sector or a particular job as stipulated in Kepmennakertrans No. Kep-233 / Men / 2003 of 2003 on the type and nature This work that is carried out continuously is done by dividing the working time into shift work / shift.

According to L. Husni ${ }^{1}$, the time required to do a job is called working time. While the nature of a human being must need rest, then to maintain health must be limited to his working hours and given the right to rest is called Workers. This is related to the reason a worker needs regulation and pay attention to working hours is a natural human nature with psychic or physical limitations in addition to

\footnotetext{
${ }^{1}$ Then Husni, 2002, Dasar-Dasar Hukum Perburuhan, PT. Raja Grafindo Persada, Jakarta, p. 46-47
} 
his role as one of the factors for production. Currently, the implementation of labor regulations is still a problem even though the rules have been set. One of the common problems is the violation of overtime work hours that do not comply with the provisions of Law No. 13 of 2003.

One of the companies that is a sample related to the implementation of labor law protection is PT Hwaseung Indonesia which is located in Jepara Regency, Central Java since 2016 and is a manufacturing company that produces worldfamous brand shoes, namely adidas. The workforce in this company reaches 15,000 employees, all of whom are still divided on supporting and Production (Assembly, Sewing and Cutting) on a large scale. In employing its employees, it is not uncommon for this company to overburden employees under certain circumstances, such as high orders and high exports.

The issue of legal protection of labor is an interesting issue to discuss. Based on this background, it is very interesting to study more deeply in a scientific work entitled "Implementation of Legal Protection for Overtime of Pt Hwaseung Indonesia". This discussion aims to analyze the implementation of labor law protection of PT Hwaseung Indonesia according to Law No. 13 of 2003 on Employment.

\section{Research Methods}

This legal research is done using the normative-Empirical method ${ }^{2}$ that is, analyze the implementation of positive law (legislation) as well as the factual contract in each particular legal event that occurs in a society that is useful to achieve a predetermined goal. This method is about the implementation of normative legal provisions in fact in a society regarding the legal protection of working hours of PT Hwaseung Indonesia.

\section{Results and Discussion}

In fact, labor law must be understood in detail in order to formulate an appropriate legal protection principle which when talking about the position of workers can actually be seen from a juridical and socio-economic point of view. Juridical, legal protection from the government is required by workers due to the possibility of unlimited action by employers. Whereas in terms of socio-economic, improving the well-being of workers is needed as protection of workers. Protection labor law is divided into three types, namely3:

a. Economic protection, that is, protection in the form of adequate income, including if the worker is not able to live his life.

b. Social protection, which is protection in the form of a guarantee of health and freedom to brush or gather to organize.

c. Technical protection, which is where labor protection is in the form of occupational safety and security.

They absolutely must be studied and implemented cooperative as employer. If the employer commits a violation, then the State's obligations start from the

2 Abdulkadir Muhammad, Hukum dan Penelitian Hukum, PT. Citra Aditya Bakti, Bandung, 2004, p.52

3 Zainal Asikin, 2004, Dasar-Dasar Hukum Perburuhan, Cet.V, RajaGrafindo Persada, Jakarta, p.76. 
lowest government to the center must carry out coaching and supervision including legal compliance with the procedures and policies of the applicable mechanism. Some aspects of labor law protection include occupational safety and health (K3), Social Security Program, Working Hours, Wages and Leave. Related forms of labor law protection that works overtime in a company. This has been regulated in Law No. 13 of 2003 on Employment.

Article 77 paragraph (1) of Law Number 13 of 2003 concerning Manpower states that every entrepreneur is obliged to implement the provisions on working hours. Article 77 paragraph (2) of the Manpower Act states that, Working hours as referred to in paragraph (1) include:

a. 7 (seven) hours per 1 (one) day or 40 (forty) hours in 1 (one) week for 6 (six) working days; or

b. 8 (eight) hours per 1 (one) day or 40 (forty) hours in 1 (one) week for 5 (five) working days.

Further Article 78 paragraph (1) of the Labor Law states that, Employers who employ workers / laborers in excess of working hours as referred to in article 77 paragraph (2) must meet the following conditions:

a. There is the consent of the worker / laborer concerned; and

b. Overtime hours can only be done at most 3 (three) hours in 1 (one) day and 14 (fourteen) hours in 1 (one) week.

Article 78 paragraph (2) of the Labor Law states that employers who employ workers beyond working hours in paragraph (1) shall pay overtime wages. Speaking of the obligation of employers to provide wages for workers who work overtime, it is stated in the Employment Law in Article 88 paragraph 3 letter b that overtime wages are one part of the wage rules that protect workers. For its implementation rules, in 2004, Menakertrans RI number KEP. 102 / MEN / VI / 2004 On Overtime Hours And Overtime Wages.

Regarding the arrangement regarding the obligation of employers to work overtime beyond working hours / overtime and the way of hiring is clearly set out in this KepMen, namely from Article 7 to Article 10. As for the interpretation from Article 7 to Article 10 Kepmenakertrans RI number KEP. 102 / MEN / VI / 2004 On Overtime Hours And Overtime Wages, among others as follows:

a. Employees employed during overtime work are entitled to:

1) Overtime wage;

2) Get a chance to get enough rest;

3) Get at least 1,400 calories of food and drink when overtime work is done for 3 (three) hours or more.

b. Feeding and drinking as referred to in paragraph (1) letter c should not be replaced with money.

Furthermore, in article 8 to article 10 is regulated regarding the wage system for workers who work overtime, while the sounds of article 8 to article 10, are as follows:

Article 8

1) Overtime wage calculations are based on monthly wages.

2) How to calculate the hourly wage is $1 / 173$ times the monthly wage. Article 9 
1) Regarding the wages of workers paid daily, then the calculation of the monthly wage is multiplied by 25 (twenty-five) for workers who work 6 (six) working days in 1 (one) week and / or multiplied by 21 (twenty-one) for workers who work 5 (five) working days in 1 (one) week.

Article 10

1) In the case of wages consisting of basic wages and fixed benefits then the basis of overtime wage calculation is $100 \%$ (one hundred percent) of wages.

2) In the case of wages consisting of basic wages, fixed benefits and non-fixed benefits, if the basic wages plus fixed benefits are less than $75 \%$ (seventyfive percent) of the total wages, then the basis of overtime wage calculation is $75 \%$ (seventy-five percent) of the total wages.

Judging from the arrangements in the Ministerial Decree above, regarding overtime working hours and overtime work wages in detail has been clearly set. Therefore, the employer is obliged to implement it. PT Hwaseung Indonesia uses a 5 working day system with 8 working hours / day and 40 hours per week, while the maximum overtime used is a maximum of 20 hours ${ }^{4}$. In fact, the Adidas employement guideline has explained where there is a conflict between Adidas work standards and local legislation, Adidas business partners are required to apply higher standards due to principles ${ }^{5}$ The basis of the Adidas group is to respect local laws and regulations in conducting its business operations.

Regarding working hours at PT Hwaseung Indonesia, based on the available data, which the normal working time in the company is from 07.00-16.00 WIB. However, it is not uncommon to have overtime / overtime at certain times such as high exports located at the beginning of the year to the middle of the year. Overtime working hours that are often applied give to workers that is around 16.00-20.00 WIB for production operators on weekdays while parts such as finish good can be until 00.00 WIB. Not to mention that, certain working hours and certain parts are not uncommon that work overtime more than 3 hours on weekdays (Monday-Sunday). Instead of high exports, PT Hwaseung Indonesia also enforces a Saturday which is a holiday for employees to enter to work overtime to complete the existing export with a maximum time limit of 60 working hours.

\begin{tabular}{|c|c|c|c|c|c|c|c|c|}
\hline & Mon & Tues & Wednes & Thurs & Fri & Satur & Week & Total WH \\
\hline $\begin{array}{l}\text { Working } \\
\text { Hours }\end{array}$ & 8 & 8 & 8 & 8 & 8 & & & 60 hours \\
\hline Overtime & 3 & 3 & 3 & 3 & 2 & 6 & & \\
\hline
\end{tabular}

Seen from the table above, it is drawn that the normal working hours of PT Hwaseung Indonesia should only apply Monday-Friday with normal working hours 8 hours / day and overtime each day is a maximum of 3 hours so the total is 54 hours / week as applied to Law No.13 of 2003. However, in fact, PT Hwaseung Indonesia employs overtime to some of its employees more than 3 hours per day and maximizes 60 hours per week. This is done to meet the export needs and

${ }^{4}$ Adidas employement guidelines
${ }^{5}$ Adidas employement guidelines 
production problems so that it takes more time to work on the production process such as bonding, the number of rejections, material delays etc. In addition to Law No. 13 of 2003 on Employment, other implementing regulations such as Article 1 Kepmen.

"The work carried out on a continuous basis is the work according to the type and nature should be carried out or carried out continuously or in other circumstances by agreement between workers / laborers with employers"

Article 3 letter k Kepmen 233 / MEN / 2003 has explained that works that if stopped will disrupt the production process, damage materials, and include maintenance / repair of production equipment.

In 1919, the ILO Convention on Work Hours 1919 (ILO Hours of Work Convention) established a standard 48 hours of work per week. Two years later, the 1921 Weekly Rest Convention made a minimum weekly rest requirement for all workers. Since then, in many countries where adidas Group does business, by law the average working hours per week has been reduced to 40 hours. Legislation governing overtime and shift work has been introduced at the local level to ensure proper protection of the health and productivity of employees.

Regarding the above, adidas employments guideline also provides the flexibility to execute its business partners for working time exceeds the normal limits of Law No. 13 of 2003 where if adidas business partner wants to employ its employees to maximize 60 hours total, then PT Hwaseung Indonesia must fulfill the agreement with employees through SPL (overtime done voluntarily) and agreement with the Workers' Union.

Judging from the above legislation and international regulations, it can be concluded that the published policies on employment are considered to be materially defective or out of sync between the law and the regulations under it, thus causing many violations of working hours performed by Indonesian companies as well as foreign investors. It is considered not to have proper legal protection for workers through laws and other government regulations where existing policies are more concerned with the interests of employers than the human rights of their employees.

Ministry of Labor of Indonesia, represented by the Department of Labor and Transmigration Jepara regency especially not perform oversight on an ongoing basis on the policies which have been published by the government. So in this case, companies in Indonesia including PT Hwaseung Indonesia have not fully fulfilled the existing Legal Compliance such as working overtime more than 3 hours per day and more than 14 hours per week. In this case, PT Hwaseung Indonesia emphasizes on international rules for its working hours, while for local regulations it is used only "the most important thing is to meet the agreement with employees, trade unions, and overtime paid in accordance with Indonesian regulations".

\section{Closing}

Legislation in the field of labor is so numerous, that there is a disharmony between one rule and another. All of this has implications for the business world, as it greatly burdens the business world and creates a less conducive investment 
climate. The legal protection enshrined in the legislation to protect the human rights of its employees has not been met. Ministry of Labor of Indonesia, represented by the Department of Labor and Transmigration Jepara regency especially not perform oversight on an ongoing basis on the policies that have been issued by the government PT Hwaseung Indonesia has not fully fulfilled the existing Legal Compliance such as working overtime more than 3 hours per day and more than 14 hours per week. In this case, PT Hwaseung Indonesia emphasizes on international rules for its working hours, while for local regulations it is used only "the most important thing is to meet the agreement with employees, trade unions, and overtime paid in accordance with Indonesian regulations".

The government wants to revise or harmonize the law in the field of Labor and not directly adopt the values contained in the ILO convention, without adapting to the conditions of Indonesian society. Revisions to labor law should be studied in depth involving all experts, both legal, economic and other fields. The revision of the Labor Law should meet the principles of equilibrium and legal protection outlined in the Outlines of the State of the Nation in order to achieve prosperity, justice, and social welfare based on Pancasila and the 1945 Constitution. PT Indonesia Hwaseung implementing legislation with Indonesia set up a schedule and plan production, adding shifts if necessary, factory managers constantly create crosstraining programs so that workers are able to perform different jobs and functions. Thus, workers from the same department and from different departments can work overtime in various positions when their co-workers are unable or unwilling to work overtime.

\section{References}

[1] Abdulkadir Muhammad | Law and Legal Research. PT. Citra Aditya Bakti. Bandung. 2004

[2] Then Husni, 2002, Fundamentals of Labor Law, PT. Raja Grafindo Persada, Jakarta,

[3] Philipus M. Hadjon, 1987, Legal Protection for Indonesian People, Bina Ilmu, Surabaya.

[4] Zainal Asikin, 2004, The Basics of Labor Law, Cet.V, RajaGrafindo Persada, Jakarta

[5] Adidas employement guidelines 